\title{
1. Mobilising the oceans to quench our thirst
}

\section{Joe Williams and Erik Swyngedouw}

How were we able to drink up the sea? Who gave us the sponge to wipe away the entire horizon? What did we do when we loosened the earth from its sun? Whither does it now move? Whither do we move? (Friedrich Nietzsche, 1974 [1882], 167-168)

\section{TAPPING THE OCEANS}

Writing in 1882 in The Joyful Wisdom (La Gaia Scienza, which could also be translated as The Gay Science), Friedrich Nietzsche - as the Madmanannounces the death of God. Standing in front of us, a crowd of sceptical onlookers, he asks "how were we able to drink up the sea?" Something has shifted, it seems, in the established order. We have changed things, and put ourselves at the top, in the position of God. In setting sail, we have broken not only the bridge behind us, but the land as well. Less than 80 years later, President John F. Kennedy famously proclaimed - in no less messianic a tone, albeit with something else in mind entirely - that "if we could ever competitively, at a cheap rate, get freshwater from saltwater ... it would be in the long range interests of humanity", which if achieved, he said, "would really dwarf any other scientific accomplishment" (Kennedy, 1961a). The consumption of the ocean by humanity in both cases represents a profound shift in society's position, in its own structure and in relation to the biophysical world. In the first instance, it symbolises our perilous extrication from the limitations of the supernatural. In the second, rather more literal meaning, the purification of saline ocean water marks the beginning of the age of abundance; the apparent emancipation of human society from resource scarcity, drought and famine; the triumph of science and engineering over nature.

This book is about the second meaning. It interrogates the rapid emergence - or what Feitelson and Jones (2014) have called a "global diffusion" - over the last two decades or so of large-scale seawater 
desalting facilities to supplement, augment or in some cases replace the water supply of cities and regions around the world. By "large-scale" we refer to facilities that go beyond supplying small communities or resorts, or providing supplementary water to fix specific management problems, but instead produce "new" potable water in quantities large enough to represent a significant proportion of municipal supply (Feitelson and Jones, 2014). While most of the desalination literature focuses on technical, engineering and managerial issues, this book explores how such techno-managerial concerns are intimately enmeshed with political, socio-ecological and economic power relations. The shift from terrestrial to marine water management engenders the transition to a radically different set of technologies, mobilising new knowledges, engaging a different set of social and economic actors, and enrolling of a new form of watery matter, which operates through, and rekindles, socio-ecological relations, geopolitical strategies, institutional configurations, flows of capital and governance arrangements. The chapters in this book explore precisely this "mattering" of saline water and the tensions and conflicts its socio-ecological metabolisation into "potable" water generates. The main objective, therefore, is to demonstrate the political character of seawater and its appropriation-cum-transformation into something usable and sellable. Enrolling seawater into a socio-ecological metabolic circuit that also assembles together all manner of capitals, technologies, politicians, social movements, institutions and hydro-managers signals how nonhuman matter enters the domain of the social and becomes mobilised and articulated with uneven and often conflicting power relations.

This perspective also points at an intellectual horizon beyond desalination. Throughout the book, the contributing authors insist that the question of ecology and the non-human cannot and should not be understood and acted upon in isolation from the myriad social and political-economic relations through which the ecological becomes cast and recast. Indeed, the rapid proliferation of large-scale desalination is intertwined with the emergence of new hydro-discursive registers, particular views on what is ecologically sound and sensible, the transformation of scales of governance, and a shift in the political-economic position of $\mathrm{H}_{2} \mathrm{O}$ within the socio-ecological circuits that sustain the contemporary capitalist order. Our ambition to politicise seawater, therefore, attempts to insert water onto the terrain of democratic polemic and contestation, and to argue that the question of democratic governance cannot be isolated from the modalities through which the non-human is appropriated, transformed and redistributed. Here precisely lies one of the key environmental challenges the world faces in the twenty-first century; namely what kind of 
socio-ecological conditions and environments do we want to produce, by whom or what, and for whom or what?

In this opening chapter, we chart the contours of and for a politicalecology of seawater desalination, and tease out the multiple tensions and contradictions that mark its rapid deployment. While providing a socio-ecological fix for conditions of relative scarcity in some places, it also opens up a host of new problems and conflicts that will undoubtedly intensify as the concern with water - its availability, uneven distribution and perversely inegalitarian access - deepens in the next decades. These conflicts will become particularly acute as the uneven patterning of the world's socio-ecological predicament will be experienced in ever more direct ways in the near future.

\section{AN EMERGING TECHNOLOGY}

The creation of potable water from seawater and other saltwater is, of course, not a new idea. As Birkett (2010) points out, desalination has a long and rich technological history which dates back far earlier than the era of large-scale municipal application. It was Aristotle who first noted, in around $320 \mathrm{BC}$, that freshwater could be extracted from seawater by thermal distillation (heating and extracting vapour) or by filtering through containers lined with wax. Similarly, there are reports of Chinese engineers 2,000 years ago using woven bamboo and earthenware filters to purify saltwater. Crude methods of thermal purification have been used on ships and in isolated communities in the Middle East since the Middle Ages and in Europe since the Enlightenment. The first patents for desalting techniques were filed in England in 1675 and 1683 by William Walcot and Robert Fitzgerald respectively, marking the beginning of a formalised desalination industry (Birkett, 2010). The first fixed desalination plant for municipal supply was constructed in Egypt in 1912 (El-Dessouky and Ettouney, 2002). It was a very small plant by today's standards, with the capacity to produce 75 cubic metres of potable water per day - about enough to meet the water needs of 600 people in Egypt today, or 200 people in the United States.

It was not until the mid-twentieth century that seawater began to be considered seriously as a potentially significant new source of water. The emergence of desalination as a major hydro-political technology was led in large part by a well-funded research and development programme administered by the United States federal government, which was coordinated by the US Office of Saline Water between 1955 and 1974. During this time government-supported research pioneered a number of important 
technologies that have shaped the subsequent development of the industry. These include the spiral-wound reverse osmosis technique - developed by a company called Reverse Osmosis General Atomic (ROGA) - that would later become the industry standard. Indeed, some have argued that the expansion of the desalination industry was made possible by this R\&D programme (National Research Council, 2008). The desalination programme during this time was international in scope and ambition. Indeed, President Kennedy was very explicit about the motivation behind his support for the programme, making it clear that United States wanted to "join with ... the scientists and engineers of other countries in their efforts to achieve one of the great scientific breakthroughs of history" (Kennedy, 1961b). The United States government even signed an agreement with the Soviet Union for the exchange of information relating to saline water conversion.

\section{Desalting Techniques}

A book about the politics of desalination would not be complete without a brief explanation of the current state of the technology. There are two broad methods of removing dissolved salt from water: thermal distillation and membrane treatment (see Table 1.1). Distillation, which put simply, involves the heating of saline water to produce de-salted steam or vapour, is the oldest commercialised method and dominated the industry until the 1990s. Of the various distillation techniques, the most commonly used is multi-stage flash distillation (MSF), which utilises a series of chambers heated to different temperatures to produce "flash" evaporation. The MSF process, which is almost always twinned with thermoelectric power generation, is favoured in some regions because of its suitability for large-scale co-production of water and energy, and is still widely used in the Middle East (Khawaji et al., 2008). For example, the largest desalting facility currently operating in the world - the Shuaibah Independent Water and Power Project in Saudi Arabia - is a hybrid plant that produces $85 \%$ of its $1,030,000 \mathrm{~m}^{3} /$ day output through a combined MSF/thermoelectric process.

Membrane processes of saline water conversion, by contrast, separate salt and water using a physical barrier. Techniques include electrodialysis, electrodeionisation, forward osmosis and reverse osmosis. Reverse osmosis (RO) is by far the dominant membrane technique, with other membrane processes being used primarily for specific industrial functions rather than municipal water supply. In the RO process, water is forced through semipermeable membranes, usually in a spiral-wound configuration, trapping dissolved salt and allowing freshwater through (Figure 1.1) (Fritzmann et al., 2007). The entire purification process usually requires at least two 
Table 1.1 The main technologies of saline water conversion, including share of global market

\begin{tabular}{|c|c|c|c|}
\hline & Technology & $\begin{array}{c}\text { Market } \\
\text { share } \\
(\%)\end{array}$ & Details \\
\hline \multirow[t]{4}{*}{ Thermal } & $\begin{array}{l}\text { Multi-stage flash } \\
\text { distillation (MSF) }\end{array}$ & 26 & $\begin{array}{l}\text { Evaporation achieved below } \\
\text { boiling point. Technology still } \\
\text { used extensively in the Middle } \\
\text { East. Almost always twinned } \\
\text { with electricity generation } \\
\text { facilities. }\end{array}$ \\
\hline & $\begin{array}{l}\text { Multiple effect } \\
\text { distillation (MED) }\end{array}$ & 8 & $\begin{array}{l}\text { Evaporation achieved at boiling } \\
\text { point. The oldest commercial } \\
\text { desalination technique. }\end{array}$ \\
\hline & Vapour compression & $<1$ & $\begin{array}{l}\text { Lower boiling temperature } \\
\text { achieved through reduced } \\
\text { pressure. Only used on a small } \\
\text { scale. }\end{array}$ \\
\hline & Solar distillation & $<1$ & $\begin{array}{l}\text { Investigated extensively but with } \\
\text { significant drawbacks, including } \\
\text { capital intensity and surface area } \\
\text { required. }\end{array}$ \\
\hline \multirow[t]{4}{*}{ Membrane } & Reverse osmosis (RO) & 60 & $\begin{array}{l}\text { Dominant desalting technology } \\
\text { since the late } 1990 \text { s. Feedwater is } \\
\text { forced through semi-permeable } \\
\text { membranes - most commonly } \\
\text { spiral wound or hollow fibre. } \\
\text { Process requires high pressure } \\
\text { (usually } 600-1,000 \text { psi for } \\
\text { seawater). }\end{array}$ \\
\hline & Forward osmosis (FO) & $<1$ & $\begin{array}{l}\text { A focus of industry R\&D but is } \\
\text { unlikely to overtake RO in the } \\
\text { foreseeable future. Currently } \\
\text { used only for specific industrial } \\
\text { applications. }\end{array}$ \\
\hline & Electrodialysis (ED) & 4 & $\begin{array}{l}\text { Is appropriate for treating } \\
\text { certain feedwaters but does not } \\
\text { compete with RO or MSF on a } \\
\text { large scale. }\end{array}$ \\
\hline & $\begin{array}{l}\text { Electrodeionisation } \\
\text { (EDI) }\end{array}$ & $<1$ & $\begin{array}{l}\text { Produces very pure water. } \\
\text { Used for specific industrial } \\
\text { applications. }\end{array}$ \\
\hline
\end{tabular}

Source: Ghaffour et al. (2013); Khawaji et al. (2008). 


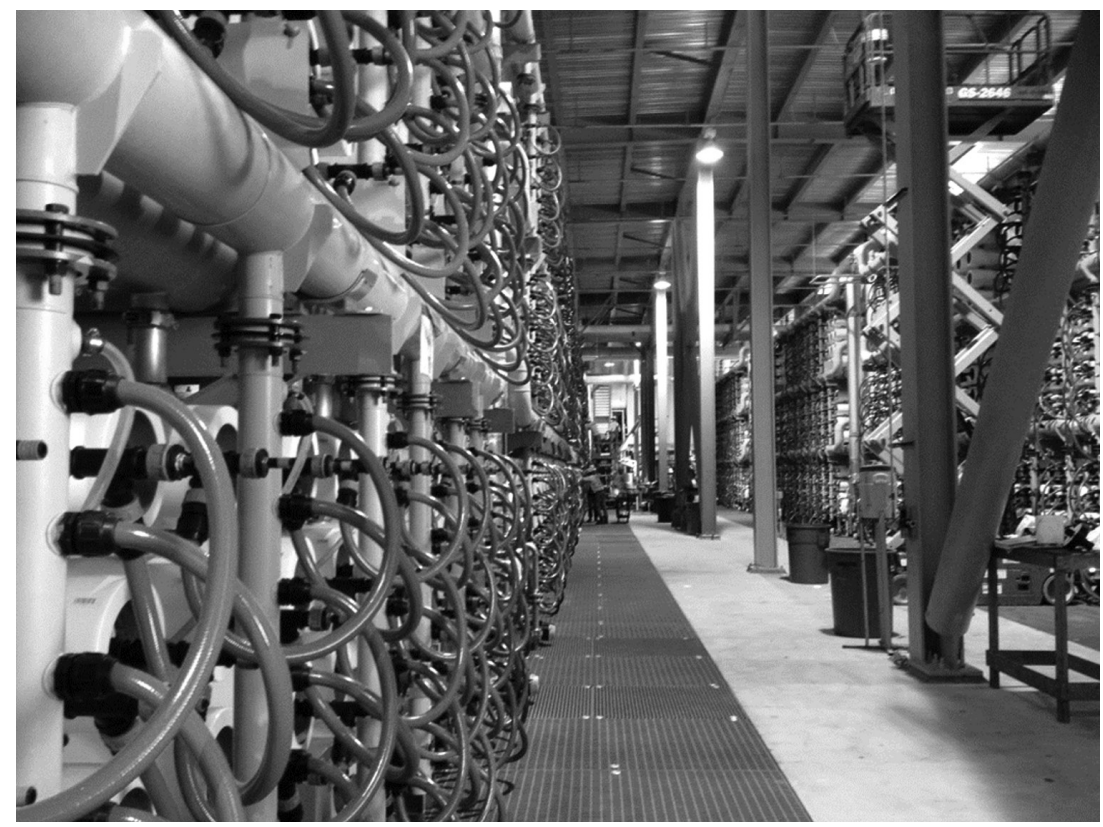

Source: Photograph: Joe Williams (2015).

Figure 1.1 Reverse osmosis units, Carlsbad Desalination Plant, California

stages of pre-treatment to remove suspended solids, the RO treatment to remove dissolved solids, and post-treatment to fix specific chemicals and for re-mineralisation. Technological improvements since the 1980s in all stages of the process, particularly in membrane performance and the development of energy recovery devices, have roughly halved both the energy requirements of treatment and the unit cost of water, making RO the preferred technique over MSF and multiple effect distillation (MED) (Greenlee et al., 2009; Malaeb and Ayoub, 2011). There is general agreement in the industry now, however, that the low-hanging fruit of technical improvements has already been taken and that further step changes in efficiency are unlikely. Notwithstanding, RO now represents a $60 \%$ - and growing - share of the global desalting market.

\section{The Global Desalting Industry}

From the 1950s to the early 2000s the uptake of large-scale seawater desalination was largely limited to the water-scarce and energy-rich regions of 


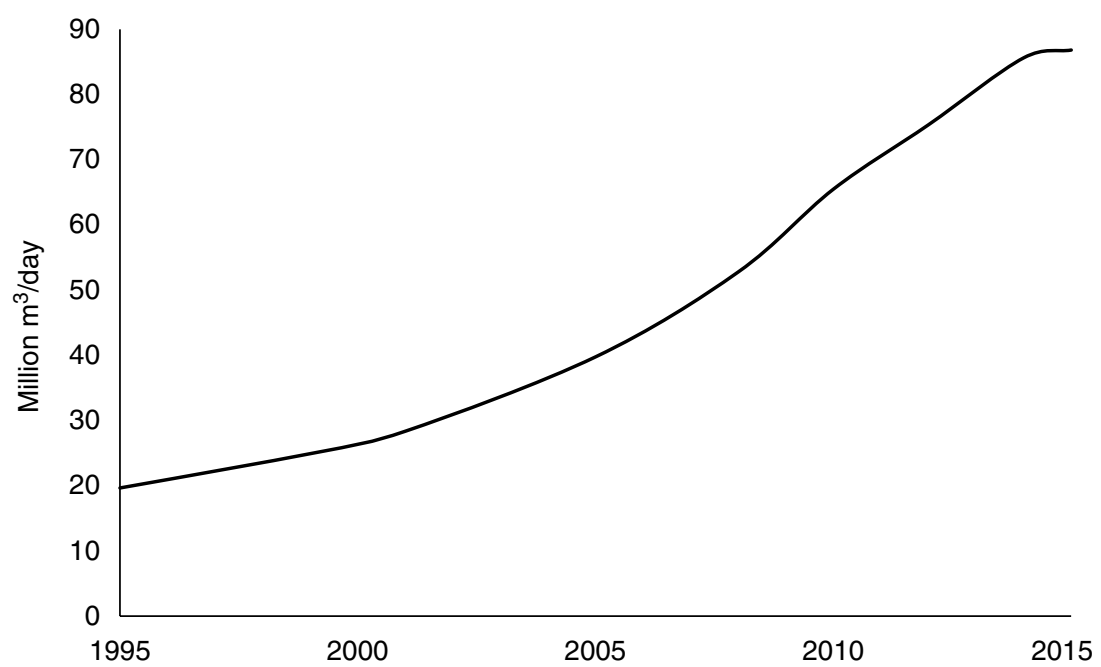

Source: Balaban (2017).

\section{Figure 1.2 Global installed desalination capacity}

the Middle East and the Arabian Peninsula. Although Kennedy's vision of a desalted future of abundance free from water scarcity was never realised, the last two decades in particular have seen a remarkable profusion of desalination facilities around the world. Total global installed capacity is growing very rapidly, from around 5 million $\mathrm{m}^{3} / \mathrm{day}$ in 1980 to nearly 90 million $\mathrm{m}^{3} /$ day in 2016 (Virgili and Pankratz, 2016). Much of this growth has occurred in the last two decades, since the step-change efficiency improvements in the RO process (see Figure 1.2). The industry analysts, DesalData, now monitor nearly 19,000 desalting facilities in 150 countries, which range in capacities of just a few cubic metres per day to over a million cubic metres per day. Worldwide, desalination plants supply drinking water for more than 300 million people (IDA, 2015). Seawater desalination accounts for around $60 \%$ of the global market, with the other $40 \%$ of desalting capacity being used in the purification of brackish groundwater and surface water $(20 \%)$, wastewater treatment $(5 \%)$, and for specialised industrial processes that require highly pure water - for instance, in the production of semiconductors (Lattemann et al., 2010; Curcio et al., 2015). The market share of seawater facilities and large-scale projects, which are the particular focus of this book, are growing (Karagiannis and Soldatos, 2008). The industry often defines "large-scale" in terms of capacity - usually over $10,000 \mathrm{~m}^{3} /$ day for "large" 
and 50,000 $\mathrm{m}^{3} /$ day for "mega" projects (Feitelson and Jones, 2014). We, however, prefer a political definition which includes desalination portfolios that represent base-load or potential base-load municipal supply, and therefore might be considered part of changing water governance paradigms. Although in terms of capacity the Middle East still is still the centre of the desalting world, investment in large desalination facilities has now expanded far beyond what Lattemann and Höpner (2008) call the desal "hotspots" of the Arabian Gulf, the Mediterranean, California, Australia and China.

The burgeoning emergence of the desalination "solution" to water stress and the global profusion of facilities has occurred in the context of disinvestment in R\&D by states and governments since the 1980s, and the extraordinary accompanying growth of a global desalting industry dominated by private enterprise. Indeed, the value of the desalting market is now estimated to be in excess of US\$31 billion (Ghaffour et al., 2013). Although the industry slowed somewhat around 2010, it has since recovered, with growth rates in terms of installed capacity at around $11 \%$ per year (GWI, 2013). In the financial year 2015-2016 around 520 new facilities were contracted, with a combined capacity of 3.5 million $\mathrm{m}^{3} /$ day (Virgili and Pankratz, 2016). The industry itself is geographically concentrated into hubs of financial and R\&D activity, including California, Florida, France, Spain, Israel, Saudi Arabia, South Korea, Singapore and Japan. In these hubs, a multitude of small and medium-sized companies operate, producing everything from membranes and membrane housing, to chemicals for cleaning and anti-scale, energy recovery devices and highpressure tubing.

Nevertheless, because of the complexity and capital-intensity of large desalting plants, the industry is dominated by a handful of companies with the financial and technical capacity to deliver facilities that can provide municipalities on a significant scale (March, 2015). The largest of these include: Veolia Environment, a French-based company with annual revenues in its Water Technologies group of US\$2 billion; Doosan, a South Korean conglomerate and winner of the 2017 GWI "Desalination company of the year" award; General Electric, whose water operations were bought by SUEZ in 2017; Fisia Italimpianti, an Italian company that produces 4 million $\mathrm{m}^{3} /$ day of desalted water, mainly in the Middle East; Degrémont, which is also owned by SUEZ; IDE Technologies, an Israeli company that specialises in desalination; and Acciona, a Spanish company that produces 2.3 million $\mathrm{m}^{3} /$ day through $\mathrm{RO}$ desalination (data from company websites, 2017). Veolia, the largest company in terms of installed capacity, accounts for around $15 \%$ of total global production of desalted water alone (Veolia, 2014). 


\section{FROM TURNKEY SOLUTION TO TECHNO-FIX}

The rapid uptake of desalting technologies to supplement and augment urban water supply is explained, justified and promoted by an emerging and increasingly dominant narrative. This narrative is presented in varying degrees and in subtly different forms by the water services industry (as represented in, for example, the publications of the aforementioned corporations), influential techno-managerial "authorities" from academic and engineering circles that prioritise technological responses to water challenges, and the government and non-government actors that promote desalination as a "solution" in a wide variety of contexts. This discursive alignment, we argue, rests on three core premises. Firstly, on a powerful and pervasive concept - and associated structures and practices - of governance that frames water as a scarce resource. In other words, a popular consensus that water scarcity is a problem that requires "new" water resources to fix is essential in justifying the huge financial and considerable socio-ecological costs of building and operating desalination plants. Yet, as critical hydro-scholars have been arguing for a long time, scarcity is not simply a physical phenomenon or function of the supply/demand relation. Kaika (2003), for example, has demonstrated how the language of scarcity has been actively mobilised as a "discursive vehicle" to build political consensus around the restructuring of the water sector in Greece. Indeed, Schmidt (2017) goes further, arguing that the rise of scarcity as "a proposition of water management" was intimately connected to the structural development of liberal capitalism in the second half of the twentieth century.

The language of scarcity and aridity permeates discussions on desalination. Balaban (2017), writing on the fiftieth anniversary of the industry journal Desalination - the pages of which, she says explicitly, provide a reflection of the development of the field - illustrates this well. "Desalination technology," she argues, "is providing water to arid wastes and turning desert lands into blossoming areas that sustain and improve the quality of life" (Balaban, 2017, xviii). Indeed, the uncritical acceptance of a mode of environmental management that understands water as scarce, either globally or in particular contexts, is, in a sense, a prerequisite to the desalination proposition. Put another way, the promotion of desalination as a viable and sustainable water source option is deeply premised on the assumption that a combination of growing demand for freshwater and dwindling or uncertain traditional supplies is contributing to growing water scarcity and a global water crisis.

The second premise is that traditional water supplies are either inadequate or unsuitable to address the growing demand/supply imbalance. 
March (2015) has placed great emphasis on this, situating the emergence of desalination over the last 20 years as a response to the collapse of the state-hydraulic paradigm. He argues that a combination of growing criticism of large dams and water transfers from environmental and social justice groups, the inability or unwillingness of national governments to fund mega projects, and the rise of demand management and soft-path approaches, has opened the doors for alternative water technologies. Seawater purification sits in a somewhat paradoxical position in this regard. On the one hand, desalination represents a departure from the hydraulic paradigm, in that it offers alternative, decentralised and (in some respects) flexible supply. But on the other hand, large desalting facilities are manifestly part of a re-imagined approach to water management that relies on capital-intense, supply-side solutions. Nevertheless, the adoption of desalination in contexts as diverse as Australia, California, Spain and South Africa (some of which are analysed in this volume) has been based in part on a rejection of previous water management practices. Former US Senator Barbara Boxer, who has lobbied the Californian governments on behalf of the desalination industry, has for example, argued that "if we sit back and we don't use ... desal... it's going to mean big dams that destroy our rivers and fisheries" (Boxall, 2017).

The final premise on which the desalination "solution" proceeds is that purified ocean water offers a water source option that is free from climate change and unreliable precipitation, free from contested terrestrial water politics and transboundary disputes, and free from competing claims to water rights and entitlements. Seawater desalination is therefore presented as a unique water management option because it "offers a seemingly unlimited, steady supply of high-quality water, without impairing natural freshwater ecosystems" (Elimelech and Phillip, 2011, 713). As Williams (this volume) points out, desalination plants are essentially factories, able to produce a commercial product (potable water) in pre-specified volumes with particular chemical characteristics, independent of the constraints that beleaguer traditional water supplies. Indeed, the industry's second largest producer, Doosan, says that its desalting plants offer "turnkey solutions" to clients wishing to address supply constraints (Doosan, 2017).

\section{The Social and Ecological Contingencies of Desalination}

The utilisation of seawater as part of a changing paradigm of water governance is, then, often presented as a silver bullet. Desalination, March et al. $(2014,2642)$ observe, "appears as a sort of "cornucopia" able in principle to solve future water needs of urban expansion". Where desalination is not presented as a silver bullet, but rather as a prudent component 
of a resilient supply portfolio - for example, in Southern California or Southeast England - it is still lauded by proponents for offering an alternative that is not encumbered by the political and ecological limitations of terrestrial water management. It is one of the primary contentions of this volume, however, that desalination is far from "free" of these constraints. Certainly, the political, institutional and social relations of seawater desalination are different in many respects to those of dams, reservoirs, pipelines and groundwater extraction wells. As the oceans are, in practical respects, unlimited, the challenges of availability certainly become less influenced by climate, geology and competing uses, and instead shaped more by energy politics, cost of production, coastal industrial zoning, marine ecology and governance structures. The extraordinary profusion of desalination in recent years, in other words, does not signal an end to scarcity, but rather a reordering of relative scarcities. Desalting plants are not free from the messy socio-material connections and contingencies that characterise terrestrial water governance, but are instead part of a reconfiguration of the social relations of water. One of our core aims in this book, then, is to engage with and uncover the social and political messiness of desalination.

The significance of context, of course, is an important aspect of this attempt to valorise complexity and contingency. The governance decisions that drive the development of desalination in Riyadh, for instance, are very different to those in Antofagasta (Cooley et al., 2006). In presenting critical perspectives on desalination, we are not critical of the technology in and of itself, but rather we are critical of the multiple and complex ways it is becoming enrolled in, and reconfiguring, the political ecology of water. As Morote et al. $(2017,10)$ point out, "desalination is neither good nor bad; its suitability depends largely on the context". This is one of the main reasons, therefore, for the structure of this book, as each chapter presents an in-depth analysis of the contextual and structural relationships that coalesce around desalination in multiple geographical contexts.

\section{Desalination as a Socio-ecological and Political Fix}

The emerging body of critical scholarship engaged with the political and social dimensions of desalination and water governance have attempted to shift the phraseology associated with this technology away from the techno-managerial language of "solution", which implies something apolitical, to desalination as a "technological fix" (Swyngedouw, 2013). The concept of the technological fix foregrounds an understanding of desalination as emerging from multiple socio-material processes, as politically complex, and as deeply contradictory. Moreover, it calls for a fuller and 
more politically astute understanding of the governance contexts in which desalting technologies are being deployed. McEvoy (2014), for instance, has argued that municipalities that pursue desalination as a supply-led strategy to improve water security may have the effect of confounding attempts to address underlying governance issues. She argues that: "[I]mplementing desalination as a technological fix on top of a water management system that is plagued with more systemic and structural problems does little to improve water security in a broader sense" (McEvoy, 2014, 534). The roll-out of desalination in particular contexts must be understood, therefore, in relation to the underlying co-evolution of water governance and economic development. Our use of this terminology in this book invokes two distinct but related notions of the technical fix.

Firstly, drawing on the work of Harvey $(1982,2014)$ and Smith (1984), among others, desalination is understood to be part of a contemporary "spatial fix" for contradictory development of capital. For these scholars, capitalism is characterised by an overall trajectory of growth, punctuated by recurrent and cyclical crises. These crises can take multiple forms, but usually threaten in some way capital's ability to reproduce its own conditions of production. The outcome of a crisis invariably involves new ways to find profitable investment opportunities, thereby re-energising growth, through geographical and ecological expansion and spatial restructuring. This is what is meant by the "spatial fix". The historical development of capitalism can, therefore, be read as a series of increasingly complex and elaborate strategies to overcome barriers to accumulation. "Resort to the spatial fix," Harvey $(1981,11)$ argues, "partially masks the irrationality of capitalism, because it allows us to attribute devaluation ... to purely political failings." The ecological dimension to the spatial fix is of course critical, O'Connor (1988) has pointed out, as a response to the environmental crises that result from capital's tendency to undermine or deteriorate the material conditions for its own reproduction. The spatial fix, in this regard, does not resolve the contradictions of capital, but rather displaces or postpones the full effects of a crisis and its implications for prevailing economic growth.

Michael Ekers and Scott Prudham (2017a, 2017b) have more recently extended this theory of the socio-ecological fix to elucidate the connections between capitalist development, environmental transformation and investment in infrastructure as fixed capital. Fixed capital (like a desalination plant), they argue, is an essential mechanism by which the metabolic interactions between humans and nature are shaped, and therefore it mediates the social and ecological for relations that underpin accumulation. Understanding the ways in which infrastructures are enrolled as socio-ecological fixes, and thereby shaping the material conditions of 
accumulation, in other words, allows us to "interrogate the political ecology of capitalist accumulation and crises thereof as they articulate with the broader politics of environmental change and everyday life" (Ekers and Prudham, 2017b, 31). Drawing on these conceptual insights, we argue that the mobilisation of seawater for municipal supply represents a socioecological fix. Water stress - and over-extraction, resource deterioration and scarcity more generally - is inextricably bound up with capitalism's growing ecological crisis. As economic development through urbanisation is premised on the continuous circulation of water, the production of "new" water via desalination provides an important strategy in guaranteeing the ecological conditions necessary for growth.

The second way in which we conceptualise desalination is as a political fix. Drawing on an emerging body of literature concerning the ecological conditions of post-politics (Kenis and Lievans, 2014; Wilson and Swyngedouw, 2014), we argue that desalination, because it is presented by the industry as a "turnkey solution" free from the constraints of terrestrial hydro-politics, is part of ongoing attempts to de-politicise water management challenges and build consensus around technology-driven management. De-politicisation by desalination proceeds through the reframing of heterogeneous and disputed water challenges as reducible to simply a problem of supply. A simple problem, moreover, with a simple technological "solution". Through desalination, complex social and material relations and political differences are, to use Murray Li's (2011) term "rendered technical". In this way, Usher (this volume) points out, desalination is being utilised not only as an alternative source of "new" water, but also as a way to diffuse or circumvent often insoluble geopolitical disputes over water allocation, access and distribution.

\section{POLITICISING SEAWATER}

Thus far, we have argued that seawater desalination, far from offering water-stressed urban areas an unproblematic supply solution, free from climate and complex disputes over allocation, represents a technical fix that is deeply contingent and politically messy. Previously, we have discussed this messiness in terms of the "contradictions" of desalination (Swyngedouw and Williams, 2016). In other words, by resolving one contradiction - that of security of supply - the development of the "marine fix" creates a series of new contradictions. We argue that desalination does not, therefore, fully resolve the problems of water governance that it seeks to address, but rather it shifts them around, crucially, reducing their immediate threat to the functioning of urban spaces as centres of 
economic growth. We now outline these contradictions under the headings of governance, economy, the water-energy nexus and ecology.

\section{The Governance Question}

Historically, water governance was primarily the concern and domain of action of state or other public bodies. From the large-scale irrigation schemes in Ancient China, Egypt or in the Latin American Aztec and Inca societies, to the grand hydraulic schemes to manage surplus waters in the Netherlands and the hydraulic conquest that marked the westward expansion in nineteenth-century USA. With a short period of budding, but quickly failing, private water management systems in the early industrial cities of the nineteenth-century Global North, urban water supply too became a matter of public policy and management. These were occasionally in association with private economic actors, but were always embedded in dense institutional configurations and with an eye towards providing universal and affordable access to water for as many people as possible.

Over the past two decades or so, the state hydraulic paradigm (with a smattering of still enduring communal, cooperative, or common management arrangements in smaller areas) that had been the master-discourse and practice of water management during much of the twentieth century became increasingly squeezed. On the one hand, the drive towards neoliberalisation and privatisation produced an ideological fantasy that pushed the management of collective resources in the direction of greater private ownership and control, while on the other hand, accusations of state failure and increasing fiscal pressures on the state, nurtured a process of privatising former state assets and the public institutions in charge of their management. This double imperative accelerated the transformation of the organisation of the hydro-social cycle in the direction of more localised, decentralised and privately operated actors, and hastened the quest for new socio-technical assemblages that could both assure expanding supply while permitting private companies to become centrally involved in significant parts of the water metabolisation and circulation process. As several chapters in the book demonstrate, the shift from large-scale, state orchestrated, terrestrial infrastructures such as dams, large-scale water transfers and the like, to decentralised desalination-based water factories profoundly altered hydraulic governance arrangements. In the process, the relationship between state and civic participation became transformed, often by increasing the distance between the techno-managerial focus of private companies on the one hand and the theatres of democratic public decision-making on the other. 
This shift from public to private water management by means of sociotechnical mutations has, of course, a profound impact on water-related investment and pricing. While public water management customarily involved forms of subsidisation, debt coverage, public investment and cross-financing, usually to assure affordable access to water to lowerincome families and to lower the cost of water for industrial sectors that depended on steady and abundant supply of water (like agriculture), the shift to private water production inserted the water economic more directly within less-regulated market environments. The combination of perceived and increasing relative scarcity, the growing demand in a context of perceived abundance provided by the mobilisation of the oceans, the uncertain future of the price of energy for energy-intensive desalination of seawater, and the cost-plus-profit accounting model of water factories, generally lead to higher water prices and, consequently, to the danger of a greater socio-ecological stratification of access to water. There is a danger, therefore, that the desalination edifice becomes caught between the hammer of rising cost and the hard rock of price increases. This may jeopardise its future while the continuing emphasis of additional water volume production takes attention away from the urgent task of considering different socio-ecological configurations to assure sustainable, just and affordable access to water.

\section{The Economic Question}

Investments in desalination factories remain a difficult and uncertain domain, marred by a range of complex and changing relations. Firstly, the profitability of large-scale desalination depends on long-term (and often cost-plus-based) secure contracts with water distribution operators, whether private or public. In addition, its economic feasibility is also crucially shaped by the regulatory and planning conditions associated with its siting, modalities of seawater extraction, and rules of brine (the highly salty residue generated by desalination) discharge. Needless to say, all manner of socio-ecological conflict and contestation may, and does, arise around every one of these conditions.

Furthermore, desalination is usually based on private investment - sometimes in conjunction with public financing in public-private partnerships - and requires tapping into globalised financial circuits (Loftus and March, this volume; Swyngedouw, 2013; March, 2015). The desalination edifice, therefore, is also a constellation that mutates the heterogeneous and complex assemblage of seawater into the concrete abstraction of a standardised and saleable commodity. Through this mechanism and its associated investments, seawater is plugged into highly complex flows 
of international fictitious financial capital circulation. In doing so, local operations nurture globalised financialisation and become embedded in the vagaries, gargantuan complexities, contradictions and cyclical crisis conditions that mark contemporary financialised capitalism.

As noted before, the desalination industry is a very concentrated business with just a few players dominating a rapidly expanding world market for desalination investment to keep up with the unquenchable thirst of a growth-based capitalist development complex. The desalination edifice is also, jointly with a range of other "green" technologies such as geo-engineering, carbon storage or electrical cars, portrayed as one of the technologies that can provide the economic means to grow out of the environmental conundrum the world is in. This green-washing technology is nonetheless dependent of large amounts of energy, which despite recent significant gains in energy efficiency, render the economics of desalination highly vulnerable to energy availability and fluctuating energy prices. The energy-related implications of desalination are explored in more detail below, and in Chapters 2, 4 and 8 .

Last but not least, desalination is of course predicated upon an appropriation and commodification of seawater (see Chapters 7 and 9 of this volume). Through the process of salt-removal and purification, seawater, which had previously not been subject to any form of human ownership, is brought under private property rights, becoming a tradable good and bearer of surplus value. Desalination, then, is a form of dispossession of one of the largest and last truly global commons, part of which is enclosed and privatised to become enrolled in a labour production process for profit and accumulation.

\section{The Water-Energy Nexus}

Seawater desalination has, in a variety of contexts, been presented as a climate change adaptation strategy because the output of a desalting plant, unlike a dam or groundwater pump, can be guaranteed, regardless of changing precipitation patterns and severe droughts (McEvoy and Wilder, 2012). But the security gained through desalination in terms of guaranteed supply can be achieved only through the application of vast amounts of energy. Indeed, the desalination of seawater represents the most energyintense economically viable source of water available to coastal cities and communities. Despite significant improvements in energy efficiency over the last three decades, current generation RO desalters require around $4 \mathrm{kWh}$ per cubic metre of water produced, although this can vary substantially depending on technology, seawater characteristics, pre- and post-treatment requirements, and so on (Cooley and Heberger, 2013). 
Notwithstanding some significant attempts within the industry to power desalination with renewable energy (Ghaffour et al., 2015), the fact is that almost all municipal-level RO facilities receive energy from the electricity grid. This means that the greenhouse gas (GHG) emissions intensity of water produced by desalination depends on the energy mix of the grid at large. Taking regional variations into account, Elimelech and Phillip (2011) have calculated that on average the production of desalinated seawater is associated with between 1.4 and 1.8 kilograms of $\mathrm{CO}_{2}$ emissions per cubic metre - or around 30,000 tons per year for a plant with a $50,000 \mathrm{~m}^{3} /$ day capacity. Simple claims, then, that seawater desalination offers a climate change adaption strategy are reductionist at best.

To complicate the matter further, given that desalination will invariably contribute towards an increase in the levels of embedded energy in a region's water supply and that energy represents the single largest variable cost in operating a desalting plant, the mobilisation of seawater for municipal supply is likely to intensify the water-energy nexus. Deepening the interdependencies between water, energy and climate through desalination may further confound the manifold tensions between the two sectors and give rise to negative trade-offs (Kurian and Ardakanian, 2015; Olsson, 2015). This could hold a twofold implication. Firstly, increasing the energy demand of the water sector may put pressure on the energy sector and reduce its adaptive capacity (Hussey and Pittock, 2012). Secondly, by effectively applying huge amounts of energy to create new water, the water sector could become more vulnerable to price and availability shocks in the energy sector (Cooley and Heberger, 2013). As a result, it has been argued by some that, when it comes to energy and climate challenges the desalination "fix" may well be a form of maladaptation, in that it may inadvertently increase vulnerability to the very issues it attempts to solve (Barnett and O’Neill, 2010; March, 2015; Juhola et al., 2016).

\section{Desalination and Ecology}

As we noted earlier, desalination has emerged as an increasingly viable (for some) water management strategy, in part as a response to the decline of the state hydraulic paradigm and growing concern over the ecological implications of large terrestrial water infrastructure for freshwater (and freshwater-dependent) ecosystems (Saurí and del Moral, 2001). In simple terms, desalination has been argued to have potentially positive environmental implications because the use of seawater reduces the need for large dams and pipelines. As the number of large-scale plants has grown, however, both the direct and indirect ecological impacts of desalination have received increased scrutiny. The issue of brine discharge received a lot of 
attention in the early 2000s amid fears that the disposal of large quantities of undiluted high-salinity discharge would damage local marine ecology. Although this remains an issue of contention, concerns about potential dead zones around desalting plants have softened (Roberts et al., 2010). Now, the issue of seawater intake arguably has higher political stakes for those critical of desalination. Two litres of seawater must be withdrawn for every litre of freshwater produced through RO. A plant with a capacity of $50,000 \mathrm{~m}^{3} /$ day, then, must withdraw $100,000 \mathrm{~m}^{3} /$ day of seawater through an intake. This can lead to the impingement (when organisms are trapped on the intake screen) and entrainment (when organisms are sucked through the intake screen) of small fish, invertebrates and larvae. Although the full effects of this are not well understood, impingement and entrainment can result in enormous loss of biological productivity (Cooley et al., 2013).

In addition to the localised ecological impacts of plants, and those already discussed associated with pollution and GHG emissions, Meerganz von Medeazza (2005) has also identified what he calls "socially-induced environmental impacts". These could occur, for example, if investment in a large emblematic supply-side solution like a desalination plant were to direct funding, research and public attention away from demand-side and conservation strategies aimed at improving water-related ecological practices. Although a comprehensive account of the complex implications of desalination for ecology has yet to be developed, it is clear that seawater does not provide an unproblematic eco-solution for the hydro-social cycle.

\section{THE BOOK . .}

The chapters in this volume present a range of perspectives that, taken together, frame a critical political ecology of seawater desalination. The contributions herein are based on in-depth case studies of cities, regions and countries that have deployed the desalination fix, excavating the socio-ecological contexts out of which this technology emerges, the political-material assemblages through which it is configured, and the new formations it engenders. The scope of the book, then, is geographically and thematically wide-ranging.

Chapters 2, 3 and 4 are concerned with the intersections between seawater desalination and the politics of water, social power and changing modes of water governance. In Chapter 2, David Saurí, Santiago Gorostiza and David Pavón chart the historical emergence of seawater desalination in Spain, from the modernist dreams of resource abundance promised by combined nuclear energy and seawater desalination in the 1960s, through 
its diminishing towards the end of the twentieth century and re-emergence in the early 2000s as a new development cornucopia, to its turbulent disciplining following the financial crisis of 2007. Their analysis shows how desalination has converged with, and become deeply implicated in, Spain's changing political, economic and ecological regime. In Chapter 3 Jamie McEvoy offers an insightful dissection of the contradictory development of desalination as a municipal water supply for the rabidly urbanising coastline of Baja California Sur, Northwest Mexico. McEvoy shows how the adoption of desalination both reinforces and disrupts broad trends in the principles of water governance towards decentralisation, privatisation, integration and stakeholder participation. Eran Feitelson, in Chapter 4, provides an analysis of water governance in Israel, where desalination is widely used as a core water supply. The extraordinary case of Israel is used to outline the direct and indirect impacts of desalination, structured around four central contradictions: the implications of perceived water abundance associated with desalination; the complex ecological trade-offs it embodies; the reconfiguration of social and political power geometries engendered in the changing geographies of water supply; and the impacts of water price increases on low-income households.

Chapters 5 and 6 are concerned with teasing out the complex ways in which desalination becomes enrolled in the politics of relative water scarcities. Maria Christina Fragkou, in Chapter 5, shows how the principal imperative towards the production of desalted seawater in Antofagasta, Chile, has been to lubricate the growth of the region's mining industry. The implications of this co-constitution between mineral extraction, industrial growth and desalination, Fragkou argues, have resulted in the fragmentation of water supply in the city of Antofagasta, persistent perceptions of scarcity and the entrenchment of class relations. In Chapter 6 Suraya Scheba and Andreas Scheba elucidate the contradictory positioning of desalination as an emergency drought-fix in South Africa's Western Cape. They identify and then seek to disrupt a dominant narrative of drought as a natural phenomenon, which has become the discursive foundation to postulate the viability of desalination as a solution. The chapter argues that the emergence of a drought-desalination assemblage overlooks the social and political production of scarcity.

Chapters 7, 8 and 9 shift focus to consider the ways in which desalination becomes implicated in the political economy of water services, and in broad trends towards neoliberalisation, commercialisation, commodification and financialisation. In Chapter 7 Mark Usher provides a detailed analysis of how desalination has become a central techno-political strategy in Singapore's quest for water independence. Usher's contention is that the seaward gaze of Singapore's water managers, which has been drawn by 
the political imperative to reduce reliance on imports from Malaysia, has prefigured the corporatisation of the water sector and established the island city-state as a commercial node in the global water industry. Alex Loftus and Hug March, in Chapter 8, discuss the relationship between desalination and water infrastructure financialisation in London. By rejecting the simplistic assumption that desalination is being developed purely to reconcile supply and demand, Loftus and March's core argument is that the construction of a desalting facility to augment Thames Water's supply must be understood as part of a broader shift in networked service provision where local infrastructural assets are leveraged to secure returns on global financial investments, with debt guaranteed against income generated from rate payers. Finally, in Chapter 9, Joe Williams provides an analysis of the convoluted development of desalination as a decentralised and local water supply for San Diego, California. Arguing that a desalination "plant" should be more accurately understood as a desalination "factory", the chapter contends that the development of large-scale seawater desalination is intimately linked to the privatisation, commercialisation and commodification of water services in general, and urban water in particular.

\section{REFERENCES}

Balaban, M. 2017. Desalination 1966-2016, The origins, evolution and role of the Desalination journal. Desalination 401: xvi-xx, https://doi.org/10.1016/ S0011-9164(16)31652-6.

Barnett, J. and O’Neill, S. 2010. Maladaptation. Global Environmental Change 20(2): 211-213.

Birkett, J. 2010. The history of desalination before large-scale use. In International Editorial Board (ed.), History, Development and Management of Water Resources, EOLSS.

Boxall, B. 2017. Barbara Boxer will lobby for an environmentally controversial desalination plant in Huntington Beach. Los Angeles Times. 19 April 2017.

Cooley, H. and Heberger, M. 2013. Key Issues for Seawater Desalination in California: Energy and Greenhouse Gas Emissions. Oakland, CA: Pacific Institute.

Cooley, H., Ajami, N. and Heberger, M. 2013. Key Issues for Seawater Desalination in California: Marine Impacts. Oakland, CA: Pacific Institute.

Cooley, H., Gleick, P.H. and Wolff, G. 2006. Desalination: with a Grain of Salt. Oakland, CA: Pacific Institute.

Curcio, E., Profio, G., Fontananova, E. and Drioli, E. 2015. Membrane technologies for seawater desalination and brackish water treatment. In Basile, A., Cassano, A. and Rastogi, N. (eds), Advances in Membrane Technologies for Water Treatment: Materials, Processes and Applications, pp.411-442. Cambridge: Woodhead and Elsevier.

Doosan. 2017. Seawater desalination plants, http://www.doosanheavy.com/en/ products/water/plant01/ (accessed 31 July 2017). 
Ekers, M. and Prudham, S. 2017a. The metabolism of socioecological fixes: capital switching, spatial fixes, and the production of nature. Annals of the American Association of Geographers 107(6): 1370-1388, https://doi.org/10.1080/2469445 2.2017.1309962.

Ekers, M. and Prudham, S. 2017b. The socioecological fix: fixed capital, metabolism, and hegemony. Annals of the American Association of Geographers 108(1): 17-34, https://doi.org/10.1080/24694452.2017.1309963.

El-Dessouky, H.T. and Ettouney, H.M. 2002. Fundamentals of Salt Water Desalination. Amsterdam: Elsevier.

Elimelech, M. and Phillip, W.A. 2011. The future of seawater desalination: energy, technology, and the environment. Science 333(6043): 712-717.

Feitelson, E. and Jones, A. 2014. Global diffusion of XL-capacity seawater desalination. Water Policy 16(6): 1031-1053, https://doi.org/10.2166/wp.2014.066.

Fritzmann, C., Löwenberg, J., Wintgens, T. and Melin, T. 2007. State-of-theart of reverse osmosis desalination. Desalination 216(1-3): 1-76, https://doi. org/10.1016/j.desal.2006.12.009.

Ghaffour, N., Bundschuh, J., Mahmoudi, H. and Goosen, M.F.A. 2015. Renewable energy-driven desalination technologies: a comprehensive review on challenges and potential applications of integrated systems. Desalination, State-of-the-Art Reviews in Desalination 356: 94-114, https://doi.org/10.1016/j. desal.2014.10.024.

Ghaffour, N., Missimer, T.M. and Amy, G.L. 2013. Technical review and evaluation of the economics of water desalination: current and future challenges for better water supply sustainability. Desalination 309: 197-207, https://doi. org/10.1016/j.desal.2012.10.015.

Greenlee, L.F., Lawler, D.F., Freeman, B.D., Marrot, B. and Moulin, P. 2009. Reverse osmosis desalination: water sources, technology, and today's challenges. Water Research 43(9): 2317-2348, https://doi.org/10.1016/j.watres.2009.03.010.

GWI. 2013. Desalination industry enjoys growth spurt as scarcity starts to bite. https://www.globalwaterintel.com/desalination-industry-enjoys-growth-spurtscarcity-starts-bite/ (accessed 17 September 2016).

Harvey, D. 1981. The spatial fix - Hegel, Von Thunen, and Marx. Antipode 13(3): 1-12, https://doi.org/10.1111/j.1467-8330.1981.tb00312.x.

Harvey, D. 1982. Limits to Capital. Oxford: Basil Blackwell.

Harvey, D. 2014. Seventeen Contradictions and the End of Capitalism. London: Profile Books.

Hussey, K. and Pittock, J. 2012. The energy-water nexus: managing the links between energy and water for a sustainable future. Ecology and Society 17(1): 31.

IDA. 2015. Desalination by the numbers, http://idadesal.org/desalination-101/ desalination-by-the-numbers/ (accessed 17 September 2016).

Juhola, S., Glaas, E., Linnér, B.-O. and Neset, T.-S. 2016. Redefining maladaptation. Environmental Science \& Policy 55: 135-140, https://doi.org/10.1016/j. envsci.2015.09.014.

Kaika, M. 2003. Constructing scarcity and sensationalising water politics: 170 days that shook Athens. Antipode 35(5): 919-954, https://doi.org/10.1111/j.14 67-8330.2003.00365.x.

Karagiannis, I.C. and Soldatos, P.G. 2008. Water desalination cost literature: review and assessment. Desalination 223(1): 448-456, https://doi.org/10.1016/j. desal.2007.02.071.

Kenis, A. and Lievens, M. 2014. Searching for "the political" in environmental 
politics. Environmental Politics 23(4): 531-548, https://doi.org/10.1080/096440 16.2013.870067.

Kennedy, J.F. 1961a. 119 - the President's news conference 12th April 1961, http:// www.presidency.ucsb.edu/ws/?pid=8055 (accessed 24 August 2014).

Kennedy, J.F., 1961b. Desalination of water. Audio tape. New horizons: a look at new developments in the fields of science and medicine. 29 June 1961.

Khawaji, A.D., Kutubkhanah, I.K. and Wie, J.-M. 2008. Advances in seawater desalination technologies. Desalination 221(1-3): 47-69, https://doi.org/10.1016/j. desal.2007.01.067.

Kurian, M. and Ardakanian, R. (eds). 2015. Governing the Nexus: Water, Soil and Waste Resources Considering Global Change. 2015 edition. New York: Springer.

Lattemann, S. and Höpner, T. 2008. Environmental impact and impact assessment of seawater desalination. Desalination 220(1): 1-15.

Lattemann, S., Kennedy, M.D., Schippers, J.C. and Amy, G. 2010. Global desalination situation. In Escobar, I.C. and Schäfer, A. (eds), Sustainability Science and Engineering, Sustainable Water for the Future: Water Recycling versus Desalination, pp. 7-39. Oxford: Elsevier.

Malaeb, L. and Ayoub, G.M. 2011. Reverse osmosis technology for water treatment: state of the art review. Desalination 267(1): 1-8, https://doi.org/10.1016/j. desal.2010.09.001.

March, H. 2015. The politics, geography, and economics of desalination: a critical review. Wiley Interdisciplinary Reviews: Water, https://doi.org/10.1002/ wat2.1073.

March, H., Saurí, D. and Rico-Amorós, A.M. 2014. The end of scarcity? Water desalination as the new cornucopia for Mediterranean Spain. Journal of Hydrology 519, Part C: 2642-2651, https://doi.org/10.1016/j.jhydrol.2014. 04.023 .

McEvoy, J. 2014. Desalination and water security: the promise and perils of a technological fix to the water crisis in Baja California Sur, Mexico. Water Alternatives 7(3): 518-541.

McEvoy, J. and Wilder, M. 2012. Discourse and desalination: potential impacts of proposed climate change adaptation interventions in the Arizona-Sonora border region. Global Environmental Change 22(2): 353-363, https://doi.org/ 10.1016/j.gloenvcha.2011.11.001.

Meerganz von Medeazza, G. 2005. "Direct" and socially-induced environmental impacts of desalination. Desalination 185(1-3): 57-70.

Morote, Á.-F., Rico, A.-M. and Moltó, E. 2017. Critical review of desalination in Spain: a resource for the future? Geographical Research, https://doi. org/10.1111/1745-5871.12232.

Murray Li, T. 2011. Rendering society technical: government through community and the ethnographic turn at the World Bank in Indonesia. In Mosse, D. (ed.), Adventures in Aidland: The Anthropology of Professionals in International Development, pp. 57-80. New York: Berghahn.

National Research Council. 2008. Desalination: A National Perspective. Washington, DC: Committee on Advancing Desalination Technology.

Nietzsche, F. 1974 [1882]. The Joyful Wisdom (La Gaia Scienza). The Complete Works of Friedrich Nietzsche 10. New York: Gordon Press.

O'Connor, J. 1998. Natural Causes: Essays in Ecological Marxism. New York: The Guilford Press. 
Olsson, G. 2015. Water and Energy: Threats and Opportunities. Second edition. London: IWA.

Roberts, D.A., Johnston, E.L. and Knott, N.A. 2010. Impacts of desalination plant discharges on the marine environment: a critical review of published studies. Water Research 44(18): 5117-5128, https://doi.org/10.1016/j.watres.2010.04.036.

Saurí, D. and del Moral, L., 2001. Recent developments in Spanish water policy. Alternatives and conflicts at the end of the hydraulic age. Geoforum 32: 351-362.

Schmidt, J.J. 2017. Water: Abundance, Scarcity and Security in the Age of Humanity. New York: New York University Press.

Smith, N. 1984. Uneven Development: Nature, Capital, and the Production of Space. Oxford: Basil Blackwell.

Swyngedouw, E. 2013. Into the sea: desalination as hydro-social fix in Spain. Annals of the Association of American Geographers 103(2): 261-270.

Swyngedouw, E. and Williams, J. 2016. From Spain's hydro-deadlock to the desalination fix. Water International 41(1): 54-73, https://doi.org/10.1080/0250 8060.2016.1107705.

Veolia. 2014. Veolia, the global leader in desalination. Veolia, https://www.veolia. com/en/veolia-group/media/news/veolia-global-leader-desalination (accessed 31 July 2017).

Virgili, F. and Pankratz, T. 2016. IDA Desalination Yearbook 2016-2017. International Desalination Association.

Wilson, J. and Swyngedouw, E. (eds). 2014. The Post-Political and its Discontents: Spaces of Depoliticisation, Spectres of Radical Politics. Edinburgh: Edinburgh University Press. 